3. N. Hagiyama et al., «Unconstrained Monitoring of Biological Signals Using an Aortic Pulse Wave Sensor,» 2018 40th Annual International Conference of the IEEE Engineering in Medicine and Biology Society (EMBC), Honolulu, HI, 2018, pp. 4327-4330.

DOI https://doi.org/10.30525/978-9934-588-79-2-2.11

\title{
МОДЕЛЬ ПРОЦЕСУ ФІЛЬТРАЦІЇ РІДИНИ ЗІ СХОВИЩА ЗА РАХУНОК ВИКОРИСТАННЯ БІОТЕХНОЛОГІЙ
}

\author{
Семененко С. В. \\ доктор технічних наук, старший науковий співробітник \\ Інституту геотехнічної механіки імені М. С. Полякова \\ Національної академії наук Украӥни \\ Демченко Т. Д. \\ аспірантка \\ Інституту геотехнічної механіки імені М. С. Полякова \\ Національної академії наук Украӥни \\ м. Дніпро, Україна
}

Для навколишнього середовища одна 3 основних загроз з боку сховищ відходів вуглезбагачення $\epsilon$ підвищення рівня грунтових вод та їх забруднення технічною рідиною. Найперспективніший способів усунення цієї загрози - зневоднення сховищ відходів вуглезбагачення $\epsilon$ висадка вологолюбних, швидкозростаючих рослин на дамбах та берегах, на достатній глибині, щоб коренева система функціонувала як губка і насос, і дозволяла видаляти воду з грунту. Найбільш поширено використання дерев сімейства вербових: верба біла, тополь різнолистий, тополь чорний, лох вузьколистий. Ці види дерев швидко ростуть і утворюють пагони, мають розвинену кореневу систему, добре розмножуються вегетативним шляхом та невибагливі до складу грунту. кожне дерево за рік випаровує $50-90 \mathrm{~m}^{3}$ грунтової води, а одна дрена на кожен метр довжини приймає і відводить $54-62$ м $^{3}$ [1]. В якості трав'яних рослин використовують жовтець повзучий, окопник лікарський, солодку, чий блискучий.

Враховуючи умови створення та експлуатації сховищ відходів переробки мінеральної сировини при розробці математичної моделі процесу фільтрації рідини зі сховища при наявності біотехногенного навантаження навкруги периметру приймемо наступні припущення: рідина, що фільтрується із сховища, є ідеальною та нестисливою [2-5]; процес 46 
фільтрації підпорядковується закону Дарсі [5-9]; став сховища в плані має круглу форму; береги ставу вертикальні по глибині; дно ставу водонепроникне; фільтрація рідини існує тільки крізь бокову поверхні берегів; водонепроникний горизонт знаходиться в грунтовому масиві нижче дна; радіус ставу значно більше його глибини; поверхня берегів навколо ставу горизонтальна; біотехногенне навантаження навкруги периметру ставу рівномірно розподілено по об'єму грунтового масиву на глибину [10], що не перевищує глибини ставу; нехтуємо впливом процесу випаровування рідини 3 денної поверхні; грунтовий масив навколо ставу не деформується; фільтраційні характеристики та параметри пор не змінюються 3 часом та однакові для всього грунтового масиву.

Таким чином, розглядається вісісиметрична задача процесу фільтрації ідеальної нестисливої рідини в пористом однорідному масиві, що не деформується, крізь бокову поверхню циліндру, у якого верхня основа співпадає з поверхню грунтового масиву, а нижня основа, знаходиться в грунтовому масиві вище чим водонепроникний горизонт (рис. 1).

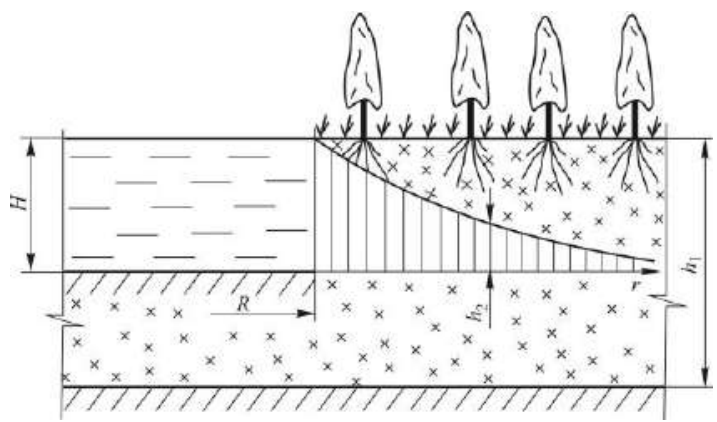

\section{Рис. 1. Формалізація процесу фільтрації рідини зі сховища при наявності біотехногенного навантаження навкруги периметру}

Грунтовий масив розподілено на дві зони - вище та нижче рівня дна циліндру. Вище рівня дна циліндру в об'ємі грунтового масиву рівномірно розподілено стоки однакової інтенсивності, які забирають рідину. Нижче рівня дна циліндру такі стоки відсутні. При цьому передбачається, що на границі областей швидкості та тиск в обох областях мають однакові значення, а на зовнішній границі другої області тиск дорівнює атмосферному.

У такий постановці, при всіх припущеннях що вищезазначені, система рівнянь фільтрації в циліндричній системі координат, початок 
якої розташовано в центрі ставу на рівні його дна, матиме однаковий вигляд, в якому рівняння збереження ваги буде відрізнятися вільним членом $[9,11]$. Для кожної з областей ці системи рівнянь можна перетворити в одне рівняння другого порядку. Після введення безрозмірних координат, та з урахуванням, що глибина ставу сховища значно менше його радіусу, отримаємо відповідні рівняння:

$$
\begin{aligned}
& \frac{\partial^{2}\left(p_{1}\right)}{\partial \varsigma_{1}{ }^{2}}=0, \quad \frac{\partial^{2}\left(p_{2}\right)}{\partial \varsigma_{2}{ }^{2}}=k \rho h_{2}{ }^{2} \delta \\
& \varsigma_{1}=\frac{z}{h_{1}}, \quad \varsigma_{2}=\frac{z-h_{1}}{h_{2}(\eta)}, \quad \eta=\frac{r}{R},
\end{aligned}
$$

де $h_{1}$ - глибина водонепроникного горизонту; $h_{2}$ - висота від рівня дна ставу до границі розподілу «повітря-рідина» в грунтовому масиві; $R$ - радіус ставу; $\rho$ - густина рідини; $g$ - прискорення вільного падіння; $k$ - коефіцієнт Дарсі [5-9]; $z$ - вертикальна координата; $r$ - радіус; $\delta$ - величина біотехногенного навантаження навкруги периметру; $p_{l}$, $p_{2}$ - тиск рідини в 1,2 області; $H$ - глибина ставу.

3 розв'язання системи (1) - (2), з граничними умовами та кінематичного співвідношення на лінії депресії $[9,11]$. Дозволило отримати наступне рівняння для визначення висоти від рівня дна ставу до границі розподілу «повітря-рідина» в грунтовому масиві

$$
\frac{d h_{2}}{d \eta}=-\sqrt{\frac{h_{2} \delta}{\frac{g}{k}-h_{2} \delta}} R, h_{2}(\eta=1)=H .
$$

Рівняння (3) є диференціальним рівнянням зі змінними, що розділяються. Інтегрування цього рівняння після введення безрозмірних комплексів дозволяє записати розв'язання у наступному вигляді:

$$
\begin{gathered}
y=\arcsin \left(\Lambda\left(\frac{\sqrt{1-X \lambda}}{\sqrt{1-X}}-\sqrt{\lambda}\right)\right)-\Lambda\left[\sqrt{\lambda} \frac{\sqrt{1-X \lambda}}{\sqrt{1-X}}-1\right], \\
y=X(\eta-1) \frac{R}{H}, \lambda=\frac{h_{2}}{H}, X=\frac{\delta k H}{g}, \Lambda=\sqrt{X} \sqrt{1-X},
\end{gathered}
$$

де $y$ - безрозмірний радіус; $\lambda$ - відносна висота границі розділу; $X$ - безрозмірна глибина ставу.

Формула (4) не дозволяє отримати залежність $h_{2}(\eta)$ аналітичним шляхом, тому результати отримані за чисельними розрахунками. 
3 рис. 2 видно, що рівень границі розподілу „повітря-рідина” в грунтовому масиві знижується зі збільшенням відстані від ставу. Це означає, що в залежності від відстані від ставу та довжини кореневої системи рослини можуть або не можуть всмоктувати рідину з грунтового масиву.

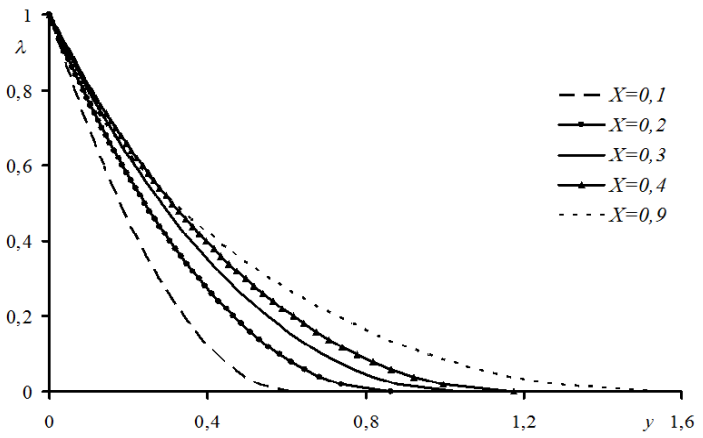

Рис. 2. Залежність відносної висоти границі розділу «повітря-рідина» в грунтовому масиві від безрозмірної відстані від ставу для різних значень безрозмірної глибини ставу

Висновок. Для розробки математичної моделі фільтрації проведено аналіз умов формування сховищ відходів вуглезбагачення, використана система класичних рівнянь теорії фільтрації, яка побудована на застосуванні закону Дарсі, за умов, що задачу можна розглядати як вісісиметричну, при наявності рівномірного біотехногенного навантаження навкруги його периметру. Запропонована математична модель процесу фільтрації дозволяє обчислити поле швидкостей рідини, що фільтрується в пористому в грунтовому масиві навколо ставу, а також розрахунковим шляхом встановити залежність граничної висоти знаходження рідини в грунтовому масиві навколо ставу від відстані від краю берега сховища. Отримана залежність комплексно враховує глибину ставу, фільтраційні якості грунтового масиву та параметри біотехногенного навантаження.

\section{Література:}

1. Прикладная экобиотехнология. / Кузнецов А. Е. и др. М. : БИНОМ, Лаборатория знаний, 2012. Т. 2. 485c.

2. Аравин В.И., Нумеров С.Н. Теория движения жидкостей и газов в недеформируемой пористой среде. М.: Госиздат, 1953. 332 с. 
3. Бернадинер М.Г., Ентов В.М. Гидродинамическая теория фильтрации аномальных жидкостей. М.: Недра, 1975. 100 с.

4. Бэр Я., Заславский Д., Ирлой С. Физико-математические основы фильтрации воды. М.: Мир, 1971. 451 с.

5. Лейбензон Л.С. Движение природных жидкостей и газов в пористой среде. М.: ОГИЗ, 1947. 156 с.

6. Гольдбер, В.М., Скворцов Н.П. Теория фильтрации. М.: Недра, 1986. $102 \mathrm{c}$.

7. Левашкевич В.Г. Нелинейные эффекты при фильтрации жидкости в пористой среде. Минск: Наука и техника, 1987. 102 с.

8. Маскет М. Течение однородных жидкостей в пористой среде. М. : Гостоптехиздат, 1949.94 с.

9. Бондаренко Н.Ф. Физика движения подземных вод. Ленинград, 1979. $214 \mathrm{c}$.

10. Пат. 142935 Україна, МПК (2020.01) В09С 1/00, В09С 1/10 (2006.01), C02F 3/32 (2006.01). Спосіб осушення сховищанакопичувача рідких відходів підприємств / А.Ф.Булат, М.С. Терещук, Є.В. Семененко, Т.Д. Демченко, Т.Д. Клокова № u201910678; Заявл. 28.10.2019; Опубл. 10.07.2020, Бюл № 13.

11. Полубаринова-Кочина П.Я. Теория движения грунтовых вод. М.: Наука, 1977. 664 с.

DOI https://doi.org/10.30525/978-9934-588-79-2-2.12

\title{
ПІДБІР КОМПОНЕНТІВ У СКЛАДІ ДЕРМАТОЛОГІЧНОГО ЗАСОБУ 3 ПРОБІОТИКОМ
}

\author{
Соловйова А. В. \\ аспірант кафедри біотехнологіi \\ Національного фармацевтичного університету \\ Калюжная О. С. \\ кандидат фармацевтичних наук, \\ дочент кафедри біотехнологіi \\ Національного фармацевтичного університету \\ м. Харків, Україна
}

Акне - одне з найпоширеніших захворювань людства, хронічне захворювання сальних залоз, яке переважно проявляється в період статевого дозрівання і характеризується гіперпродукцією шкірного сала, 